
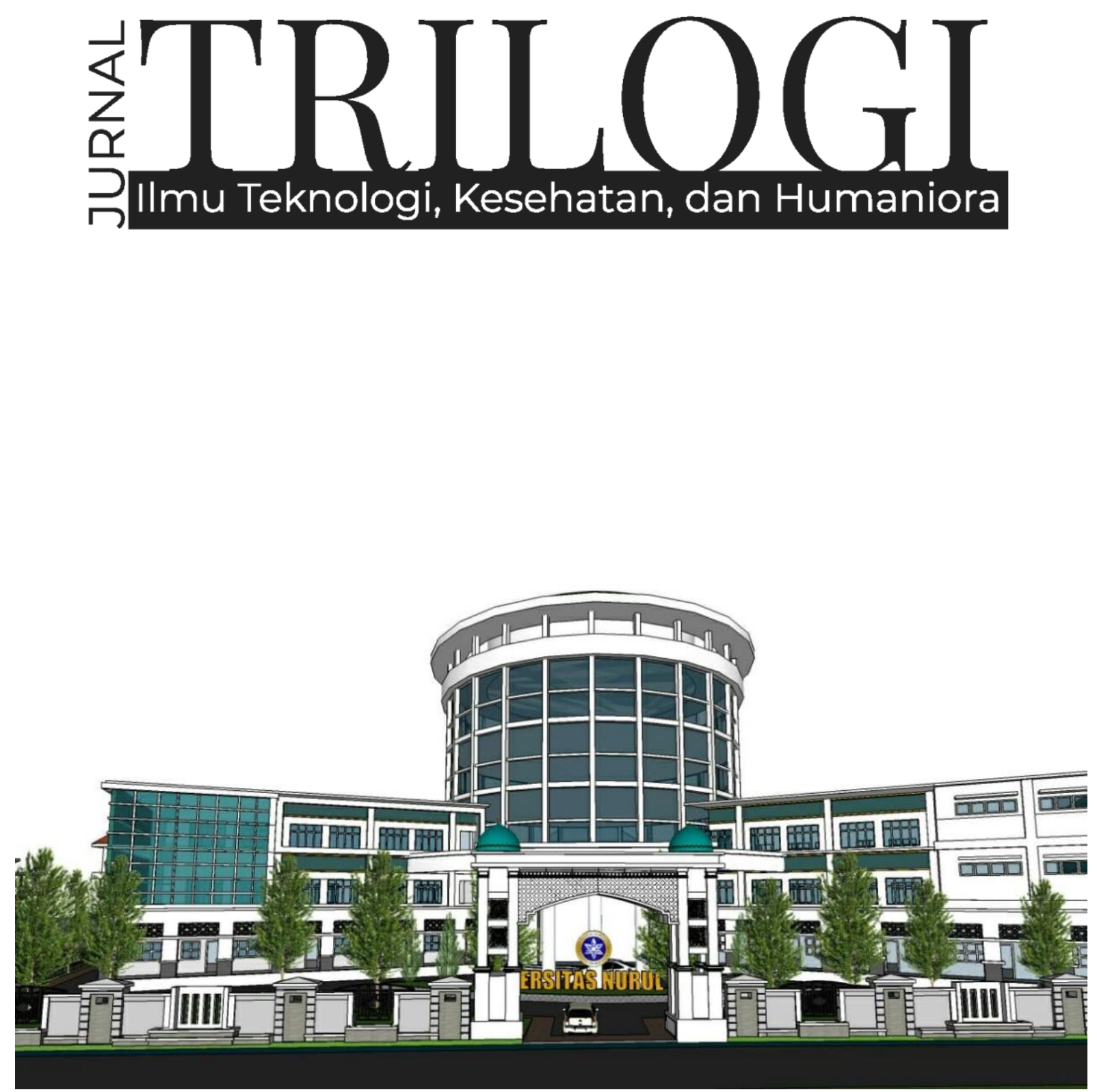

PENGEMBANGAN PENDIDIKAN DAN EKONOMI PESANTREN DI MASA PANDEMI COVID-19 


\section{犃BUOGI}

Vol. 2, No. 2, 2021

Editor in Chief

Achmad Fawaid, (SCOPUS ID: 57214837323)

\section{Managing Editors}

Hasan Baharun, (ID SCOPUS : 57200983602)

Sugiono Sugiono, (SCOPUS ID : 57199578160)

Ismail Marzuki, (SCOPUS ID: 57201500245

Subhan Rachman, (SCOPUS ID: 57192937912)

Nurul Huda, (SINTA ID: 6119615)

Syamsuri, (SINTA ID: 6116825)

Ridhatullah Assya'bani, (SINTA ID: 6200862)

\section{Peer Reviewers}

Miftahul Huda, (SINTA ID: 6171566), University of Antwerp, Belgium

Achmad Naufal Irsyadi, (SINTA ID: 6704870), Universitas Nurul Jadid, Indonesia

Gulpi Qorik Oktagalu P., (SINTA ID: 5982074) Universitas Nurul Jadid Probolinggo, Indonesia Hozairi, (SINTA ID: 166198), Universitas Islam Madura, Indonesia

Nur Hamid, (SINTA ID : 6744813), Univeristas Nurul Jadid Probolinggo, Indonesia Zainal Munir, (SINTA ID: 6672512), Universitas Nurul Jadid Probolinggo, Indonesia Sri Astutik Andayani, (SINTA ID: 6172559), Universitas Nurul Jadid Probolinggo, Indonesia Sukamto Sukamto, (SINTA ID: 5979034), Universitas Widya Gama Malang, Indonesia Deny Utomo, (SINTA ID: 6016108), Universitas Yudharta Pasuruan, Indonesia Fariz Alnizar, (SCOPUS ID: 6659824), UNUSIA Jakarta, Indonesia

Fuad Rahman, (SCOPUS ID: 57201474778), UIN Sulthan Thaha Saifuddin Jambi, Indonesia Saifuddin Zuhri Qudsy, (SCOPUS ID: 57213595165), UIN Sunan Kalijaga Yogyakarta, Indonesia Akhmad Anwar Dani, (SINTA ID: 14305), IAIN Surakarta, Indonesia

Maufur Maufur, (SINTA ID: 5989329), IAIN Kediri, Indonesia

Siti Mahmudah Noorhayati, (SINTA ID: 6726997), IAIN La Roiba Bogor, Indonesia Busro Busro, (SCOPUS ID: 57205022652), UIN Sunan Gunung Djati Bandung, Indonesia Akmal Mundiri, (SCOPUS ID: 57205059378), UNUJA Probolinggo, Indonesia

\section{Section Editor}

Ahmad Zubaidi, Universitas Nurul Jadid, Probolinggo, Indonesia 
TRILOGI: Jurnal IImu Teknologi, Kesehatan, dan Humaniora is a peer-reviewed journal, open-access journal which publishes original articles on various issues within technology, health, and social humanities, which include but are not limited to newrenewable energy, food-agriculture, health-pharmacy, transportation, informationcommunication technology, advanced-materials, maritime-infrastructre, social-artseducation, and religious studies based on academic and scientific research.

TRILOGI: Jurnal IImu Teknologi, Kesehatan, dan Humaniora seeks to publish a balanced mix of theoretical or empirical articles, case studies, review papers, comparative studies, exploratory papers, and book reviews. All accepted manuscripts will be possibly published both online and in printed forms.

Editorial Office:

TRILOGI: Jurnal IImu Teknologi, Kesehatan, dan Humaniora Lembaga Penerbitan, Penelitian, dan Pengabdian kepada Masyarakat (LP3M) Universitas Nurul Jadid, Paiton, Probolinggo, Jawa Timur, Indonesia 67291.

Phone: 088830 77077, Hp: 082318007953

Email: jurnal.trilogi@gmail.com

Website: https://ejournal.unuja.ac.id/index.php/trilogi/index 


\section{Tables of Content}

71-76

Pengaruh Metode Pembelajaran Daring dengan Aplikasi Google Classroom terhadap Hasil Belajar Siswa Madrasah Ibtidaiyah Nurul Mun'im Paiton Probolinggo

Feriska Listrianti, Lailatul Munawwaroh, Sayyidatul Arifa, Siti Aisyah

77-84

Inklusivitas dan Responsivitas Pesantren dalam Penanganan Pandemi Covid 19: Telaah Hidden Curriculum Pembelajaran di Pondok Pesantren Nurul Jadid

Zakiyah BZ, Uswatun Hasnah, Nafistur Rahmah

84-94

Integrasi Kurikulum Madrasah Diniyah dengan Lembaga Formal dalam Meningkatkan Mutu Lulusan di Sekolah Menengah Pertama (SMP) Nurul Jadid Paiton Probolinggo

Abdurrahman, Ika Fitri Anwar, Sofiya Mauliza, Nadya Afkarina

95-104

Some Issues on Time Deposit Financing: An Islamic Perspective on Mudharabah Agreement at Baitul Maal wa Tamwil (BMT) NU in Randuagung Lumajang

Saifuddin, Abdul Hafid, Hengki Wahyu Pratama

$105-110$

Analisis Pengembangan Potensi Ekonomi Keluarga melalui Unit Usaha Kapuk

Fahrudin, Iis Sa'diyah, Rizaldi Chandra Gunawan

111-117

Penguatan Ekonomi Pesantren melalui Pengembangan Ekonomi Masyarakat Pesisir: Pelajaran dari Pondok Pesantren Nurul Jadid Paiton Probolinggo

Achmad Febrianto, Muhammad Habibullah, Aksal Ilhamsyah

118-125

Prevensi Perilaku Konsumtif Persepektif Abraham Maslow dan Tri Logi Santri

Muhammad Syaiful Suib, Habibatur Rizkiyah, Fitria Nur Ain 
$126-136$

Manajemen Pengembangan Kurikulum Berorientasi pada Pembentukan Karakter

Moh Rifa'i, Fatimah Al Zahra, Abdurrahman Abdurrahman, Mukhlisin Saad

137-147

Home Industry, Kaderisasi, dan Santripreneur

Muh Hamzah, Aprilinda Dwi Kurniawati, Husnul Khotimah

148-157

Rancangan Pengelolaan Nirsampah Mandiri Skala Lembaga Pendidikan

Tirmidi, Eril Sinta Nuriyah, Rofi'ah

158-166

Parents' Knowledge and Commitment To Stimulate Child Development

Lailatul Fitriyah, Nurul Islamiyah, Auliya' Fatahillah

167-172

Implementasi Pembelajaran Akhlak Berbasis Multikultural pada Masa Pandemi di Madrasah Tsanawiyah Nurul Jadid Paiton Probolinggo

Abdullah, Yusrolana, Nur Laily

$173-183$

Implementasi Evaluasi Pembelajaran Daring (Online) melalui Home Visit

Moch Tohet, Moh. Bagus Abdillah, Adam Hakim Al Rizki

184-192

Efektivitas Pembelajaran Luring pada Mata Pelajaran Matematika selama Pandemi Covid-19

Zaenol Fajri, Sukron Junaidi, Hamdani Alfarisi 
P-ISSN: 2774-4574; E-ISSN: 2774-4582

TRILOGI, 2(2), Mei-Agustus 2021 (158-166) @2021 Lembaga Penerbitan, Penelitian, dan Pengabdian kepada Masyarakat (LP3M) Universitas Nurul Jadid Paiton Probolinggo

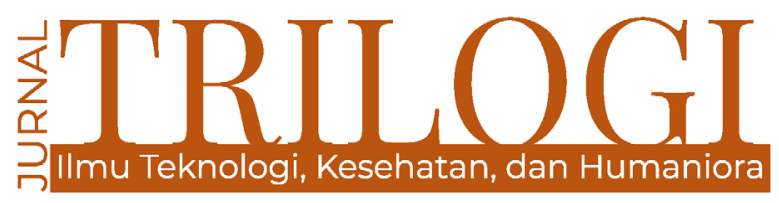

\title{
PARENTS' KNOWLEDGE AND COMMITMENT TO STIMULATE CHILD DEVELOPMENT
}

\section{Lailatul Fitriyah}

Universitas Nurul Jadid, Probolinggo

lailatulfitriyah15.If@gmail.com

\section{Nurul Islamiyah}

Universitas Nurul Jadid, Probolinggo

islamiyahnurul418@gmail.com

\section{Auliya'fatahillah}

Universitas Nurul Jadid, Probolinggo

auliyafatahillah@gmail.com

\begin{abstract}
Parents of early childhood need to assert themselves as parents who are ready to oversee the development of their children. In this paper, we will present the results of our research on respondents as parents rather than early childhood, specifically regarding their knowledge and commitment to efforts to stimulate child development. Through the methods of observation, interviews, and filling out questionnaires, we formulated 7 research findings. The 7 findings in question are: 1) PAUD parents mostly live with parents/in-laws, 2) parents of early childhood mostly work as employees and spend most of their day working, 3) parents of early childhood women Small children who work as housewives spend most of the afternoon taking care of the house, 4) PAUD Parents Want Their Children to Develop Well, 5) Early Childhood Parents Want to Stimulate Early Childhood Development, 6) Parents Constraints Obstacles to Early Childhood Opportunities (Free Time) to Stimulate Development, and 7) Early Childhood Parents Limit Knowledge to Stimulate Development. Most of the PAUD parents we met said that they were ready and would try to provide the best education and stimulation for their children's development. However, when faced with difficulties, work, time, and finances, they also appear to be indecisive and think hard. As if true to them, no matter how they try to respond positively, parenting is a difficult and stressful matter.
\end{abstract}

Keywords: parent; developmental stimulation; child develompment 


\begin{abstract}
Abstrak
Orang tua daripada anak usia dini perlu menegaskan dirinya sebagai orang tua yang siap untuk mengawal perkembangan anak mereka. Dalam naskah ini kami akan menyampaikan hasil penelitian kami terhadap responden sebagai orang tua daripada anak usia dini, tepatnya mengenai bagaimana pengetahuan dan komitmen mereka terhadap usaha stimulasi perkembangan anak. Melalui metode observasi, wawancara, dan pengisian angket, kami merumuskan 7 temuan penelitian. 7 temuan yang dimaksud adalah: 1) orang tua anak usia dini sebagian besar tinggal bersama orang tua/menantu, 2) orang tua anak usia dini sebagian besar bekerja sebagai karyawan dan menghabiskan sebagian besar waktu sehariannya untuk bekerja, 3) ibu daripada anak usia dini kebanyakan berprofesi sebagai ibu rumah tangga yang menghabiskan sebagian besar sore hari mengurus rumah, 4) semua orang tua anak usia dini menginginkan anak mereka berkembang dengan baik, 5) orang tua anak usia dini memiliki keinginan untuk dapat merangsang perkembangan anaknya, 6 ) ornag tua anak usia dini mengalami keterbatasan waktu khusus untuk dapat melaksanakan program stimulasi, dan 7) orang tua anak usia dini memiliki keterbatasan pengetahuan untuk melakukan stimulasi perkembangan. Sebagian besar orang tua anak usia dini yang kami temui mengatakan bahwa mereka siap dan akan berusaha memberikan pendidikan dan stimulasi terbaik untuk perkembangan anak-anak mereka. Namun, ketika dihadapkan pada masalah kesulitan, pekerjaan, waktu, dan keuangan, mereka juga terlihat ragu-ragu dan berpikir keras. Seolah-olah benar bagi mereka, tidak peduli bagaimana mereka mencoba merespons secara positif, mengasuh anak adalah masalah yang sulit dan menegangkan.
\end{abstract}

Katakunci: orang tua, stimulasi perkembangan, perkembangan anak

\section{Introduction}

Giving stimulation aims to help children to develop, children who are well stimulated can achieve developmental aspects well. Stimulus is given through early childhood education, through education children are given learning through play. Stimulation can be given in various forms that are simple and easy to do. The stimulation can be in the form of warmth and sincere love given by parents. In addition, parents can provide direct experience by using their five senses (sight, hearing, taste, touch, and smell).

The development experienced by the child is not at all a reason to stop the habits of his childhood. This will actually help parents in maintaining an open line of communication. The family is the smallest social unit that has an important role and is the basis for early childhood development. The relationship between parents and children will develop well if both parties foster mutual openness. Speaking and listening are very important.

Development lasts a lifetime, while growth experiences a certain time limit. Development is related to things that are functional, while growth is biological. For example, growth in height begins at birth and stops at the age of 18 . The functional development of the eye, for example, undergoes tidal changes from birth to death. Development in English is called development. Santrock (2011) defines development as a pattern of change that begins at the time of conception and continues throughout life. The term development includes the terms development and growth. Development is oriented to mental processes, while growth is more oriented towards increasing size and structure.

According to Hurlock (1980), basically two developmental processes, namely growth or evolution and decline or involution, occur simultaneously in human life. This shows that development is not only progress but also setbacks. Development includes things that are qualitative and quantitative. In the development of early childhood there is also a process of change that is progress and decline, for example, children grow teeth but at the same time children experience pain due to these teething.

Early childhood is in the golden age. This period is called the golden age because at this age there is a very amazing and best development at an early age. This amazing development includes physical and psychological development (Masganti, 2017). From a physical point of view, children experience extraordinary development, starting from the growth of brain cells and other organs to the development of gross motor skills such as walking, running, jumping, climbing, and so on. Another physical development that is no less important is fine motor development, which is the ability to coordinate hand and eye 
movements, for example grasping, reaching, writing, and so on.

In addition to physical development, psychological development also experiences amazing things, from the ability to interact with one's own parents to the ability to interact with other people. Starting from sensori-motor thinking skills to pre-operational-concrete thinking skills. Children at the sensori-motor stage can only understand something after using their senses, but then that understanding develops at the concrete operational stage into an understanding of objects mixed with the child's imagination. The development of this cognitive ability contributes greatly to language skills, emotional abilities, moral abilities, and even religious abilities. At an early age children learn the first word followed by thousands of subsequent words. At an early age, children begin to interact with people around them, from their parents to the community around them. At an early age children begin to be able to distinguish between good and bad, and at an early age children also begin to know the name of God and his religion.

Stimulation can be given in various forms that are simple and easy to do. The stimulation can be in the form of warmth and sincere love given by parents. In addition, parents can provide direct experience by using their five senses (sight, hearing, taste, touch, and smell). The interaction of children and parents through touching, hugging, smiling, singing, and listening attentively is also a form of early stimulation. When a child who has not been able to speak babbles, the babbling needs to get a response as a form of stimulation of the child's speech ability. From an early age, parents should invite conversations in a soft voice and give children a sense of security. Before the age of 3 years, stimulation is directed to achieve all aspects of development (vision, hearing, cognitive, social-independence, fine movement, gross). After the age of 3 years, stimulation is directed more specifically to academic readiness: drawing, recognizing shapes, letters, numbers, writing, reading, counting, in addition to socialemotional and independence (Essa, 1996).

Giving stimulation is a way to help children to develop, children who are well stimulated can achieve developmental aspects well as well. Stimulus can be given through early childhood education, through education children are given learning through play. According to Vigotsky (Hartati, 2005) argues that the experience of social interaction is important for the development of children's thinking processes. Mental activity in children can be formed through interaction with other people. In this case it can be said that learning is an opportunity for children to create and manipulate objects or ideas.

Learning in early childhood is basically playing. In accordance with the characteristics of early childhood who are active in conducting various explorations of their environment, playing activities are part of the learning process. Learning is directed at developing and perfecting the potential abilities possessed such as language skills, social-emotional, physical motor and cognitive (intellectual). Bredekamp (Masitoh, Setiasih and Djoehaeni, 2005) said, "Play is an important vehicle for children, social, emotional, and cognitive development". This means that play is an important vehicle for children's social, emotional, and cognitive development which is reflected in activities.

With the theoretical background above, the researchers intend to carry out research with the theme: Analysis Of Parents' Knowledge And Commitment In Paiton - Proboliggo To Stimulate The Development Of Children.

\section{Method}

The research was conducted with a descriptive qualitative approach using questionnaires, questionnaires, and observation guidelines. All data were collected to describe how the motivation and commitment of early childhood parents to carry out stimulation programs to guarantee the quality of their child's development. The research was conducted from February to March 2021.

Observations on research subjects were carried out in the closest area of Nurul Jadid University, namely in the Paiton District, Probolinggo Regency. This area includes 20 villages, namely: Alas Tengah, Binor, Jabung Wetan, Jabung Candi, Jabung Sisir, Kalikajar Kulon, Kalikajar Wetan, Karanganyar, Paiton, Pandean, Petunjungan, Plampangan, Pondokkelor, Randumerak, Randutatah, Sidodadi, Sukodadi, Sumberanyar, Sumberejo, and Taman. From the results of this activity, 110 families with an average age of the head of the household were 33 years old and the mother was 30 years old who were scattered and taken randomly in the Paiton area. The educational strata of the heads of families are mostly high school graduates $(53.6 \%)$, the highest graduates are masters $(1.8 \%)$ and the lowest are elementary school 
graduates $(10 \%)$. The occupation of the head of the family as entrepreneur (52\%), farmer $(25 \%)$, private employee (19\%), and teacher (5\%); and mothers as housewives $(68 \%)$, farmers $(13 \%)$, teachers $(7 \%)$, entrepreneurs $(7 \%)$, and private employees $(5 \%)$.
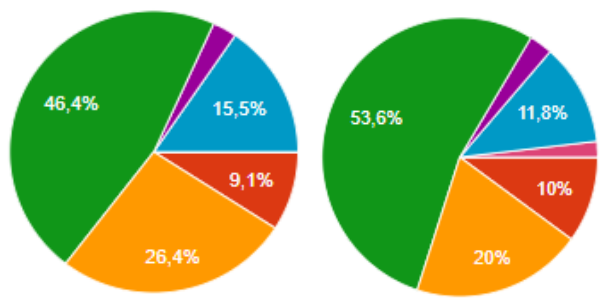

Tidak ada

SD

SMP

SMA

- Diploma

s1

$\mathrm{s} 2$

53

Diagram of the education level, of father (left)

and mother (right) in the target of socialization

The research was conducted by distributing students to conduct restructuring interviews while filling out questionnaire data and integrated questionnaires using Google Forms. The Google form contains a formula for early childhood family data, several Likert-scale questionnaires to measure attitudes, and several essay question points which will then be filled out carefully by field researchers according to the statements, responses, or answers of each respondent.

\section{Result and Discussion}

In this discussion, 7 concluding findings from all field data obtained by researchers will be presented. The 7 findings in question are: 1) Parents of Early Childhood Mostly Live with Parents / In-laws, 2) Parents of Boys of Early Childhood Mostly Work as Employees and Spend Most of the Day Time to Work, 3) Parents of Children Early childhood women who work as housewives spend most of the afternoon taking care of the house, 4) Early Childhood Parents Want Their Children to Develop Well, 5) Early Childhood Parents Want to Stimulate Early Childhood Development, 6) Parents Early Childhood Constraints Opportunities (Free Time) to Stimulate Development, and 7) Parents of Early Childhood Constraints Knowledge to Perform Developmental Stimulation

\section{1) Parents of Early Childhood Mostly Live with Parents/In-Laws}

In terms of living conditions, $43.6 \%$ of the target stated that his family lived with their parents at their parents' house. $1.8 \%$ live at home and are still with their parents, $0.9 \%$ live at their parents' house but are without parents, and
$53.6 \%$ live at home alone. The large number of initial families with the status of living at the house of their parents/in-laws while simultaneously living with their parents is a common condition that we find in Paiton District. Most of the early families with only children at an early age are still starting their family's economy and of course they still rely on their parents for part of their life, especially for housing.
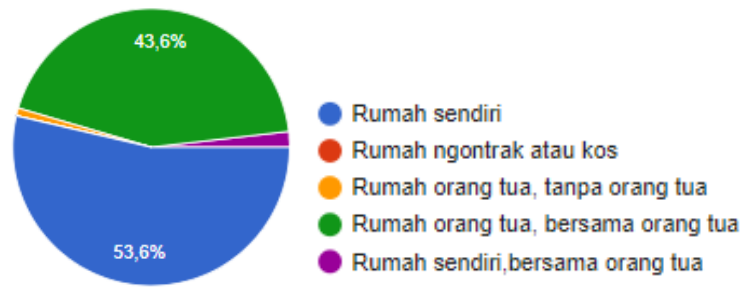

The phenomenon of new households who then decide to live with their parents or in-laws after marriage or in the early stages of marriage does not only occur in Indonesia. This has become the culture of society in Asia. Several studies on families in China also show the same thing. Pimentel \& Liu (2004) studied 2 married couples. The results of the study indicate that couples who are married and live in the wife's parents' house have a tendency to not be independent, do not develop normatively, and have a dependency in fulfilling their own life resources. In relation to children, they do not have significant policy authority over the upbringing of their children, because of parental control or involvement. The patrilineal family system in China causes many married couples to fall into this condition.

Slightly different but the effect is the same, the absence of the power of a married couple on their married life, also occurs in India. In India, the opposite applies to China, where the wife must join the husband's family. Dixit et al (2021) examined the pressure on young women in India in the early days of marriage that was received from in-laws or husband's parents, where the problem that often arises is the problem of changing habits (behaviors).

This is also what seems to happen to young couples in Indonesia who apply the status of living with in-laws. Psychologically they are pressured to have to adjust their daily living habits with the new rules of life, which are applied at the in-laws' house. Maybe the goal of supporting financially by covering basic needs (eating, drinking, and buying household items) doesn't always end well. Dependence on parents makes married couples never get independence both economically and 
in managing their household life. It does not stop there, when children are born and develop, parents-in-law who are too involved or interfere in the development of children result in these young parents not having full policy authority over the development of their children. Some are lulled by the help of parents in raising children, so they do not have a full role. Others want to do developmental coaching but are hindered by the different ways of educating their parents-in-law to their grandchildren.

\section{2) The parents of young boys mostly work as employees and spend most of the afternoon working; 3 ) Parents of young girls who work as housewives spend most of the afternoon taking care of the house}

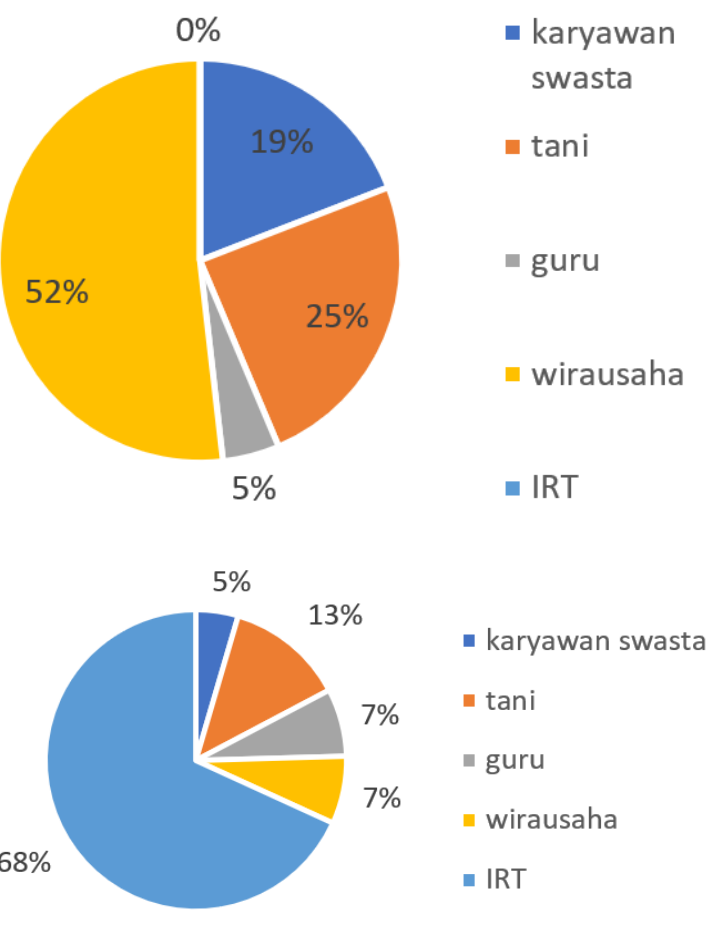

Dillaway \& Pare (2008), describes the results of research from a cultural point of view regarding "stay at home mothers" or "full-time mothers" and "working mothers". In the view of western culture, it may be seen that it has become part of women's human rights to have a career rather than being a housewife whose entire time is spent at home. Therefore, mothers who work outside the home will find it difficult to spend time with their children and then transfer them to housekeepers / babysitter / or parents / in-laws. On the other hand, some people think that being a housewife will be good for the child's development, because it is directly fostered by the mother and to give enough time and attention. Even Son \& Bauer stated that there is a negative impact due to conditions where a mother has to work to meet economic needs, as a result of the problem of low income, namely the lack of attention to children to have an impact on developmental problems and delinquency.

However, the facts we found are not as beautiful as people talk about "the importance of the role of a mother who always takes care of her child all the time". Housewives / "stay at home mother" / "full-time mother" cannot always devote time to children. Their homework is not as simple as it seems to the people behind the walls of the house. At home, a housewife spends her time cleaning the house, washing, ironing, cooking, and various other jobs that are not easy or quick to complete. In the end, it is not much different from being reluctant to work in the office, they can rest during the day and will even continue their work in the afternoon. What about the kids? In fact, they still get a less portion to be able to fulfill their need for development stimulation. Of course with a note, we're talking about a family without a housemaid. It might be different if there is one or several housemaids in the house. However, in our study, early childhood parents were early household organizations that were still in financial trouble, which would certainly rethink paying for a domestic helper.

\section{3) Early Childhood Parents Want Their Children To Develop Well; 5) Early Childhood Parents Want to Stimulate Early Childhood Development}

Every parent's desire is to see their child develop well. Various efforts will certainly be made to meet the needs of children. Qualitative research by Sidebotham (2008) shows that parents perceptually, however they hold on to a positive perspective for their efforts to raise children, still enter the perception of the parenting process as something stressful. This is exacerbated by social structures and attitudes that do not respect or support children and their families, especially in their efforts.

Analysis of Sidebotham's research data suggests several key areas where culture imposes certain pressures on parents and, as such, does not support families or children. Areas of stress that stand out are time pressure, particularly in terms of work vs. home affairs, children's expectations to be active and achievers, financial pressures and the impact of consumerism on families. 
This condition was also found in the condition of our research subjects. Most of the early childhood parents we met said they were ready and would try to provide the best education and stimulation for their children's development. However, when faced with problems of difficulty, work, time, and finances, they also look doubtful and think hard. As if it is true that for them, no matter how they try to respond positively, parenting is a difficult and stressful issue.

\section{4) Parents of Early Childhood Constraint Opportunities (Free Time) to Stimulate Development}

Regarding the dominant time of the child with his family, $90.9 \%$ of the children had the dominant time with the mother, $7.3 \%$ with the grandmother, and $1.8 \%$ with the father. This is in line with the number of mothers with the status of housewives.

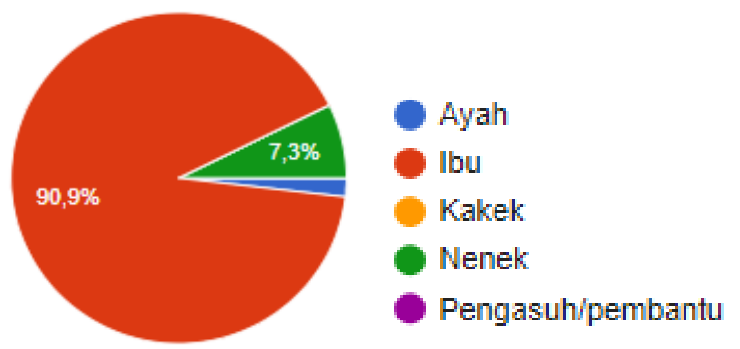

Polatnick (2002) wrote about the quantity of time a child needs with his parents who work full time. Through in-depth interviews with children, it was found that children feel deep disappointment, much worse than it appears on the outside. Family, social, and economic pressures influence them to suppress feelings/desire to be with their parents. This will have an impact on the child's dissatisfaction with the relationship with his parents.

As previously explained, our respondents are full-time people who spend most of the day at work. Even mothers who do not work / housewives also spend a lot of time taking care of housework.

In the graph above, quantitatively, when asked about the dominance of time together, most of them answered that their children were dominant with their mothers. However, this togetherness apparently cannot be equated with the time of attention. This is because mothers only accompany their children, not to pay attention in full focus to then guide the training and stimulation of their child's growth and development. In an illustration of a real situation, for example, a mother takes her child to the kitchen, gives him some toys, while the mother cooks next to him.

Not to mention if the problem of quality time together between mothers and children is controlled due to gadgets and television problems. Some mothers who are resting from their activities are sometimes too tired or lazy to then do activities that focus on their children. They prefer to entertain themselves by playing gadgets/mobile phones/smartphones or watching television. This has been the subject of research by Kushlev \& Dunn (2018), they found further evidence that smartphones can distract parents from reaping a sense of social connection when spending time with their children. These studies show that being constantly connected to the Internet can bring subtle costs to the fabric of social life.

Apart from mothers, the children in our respondents also have a dominant time with their grandmothers and fathers. Children with dominant time with grandmother are children whose both parents work so that grandmother replaces the mother's role to take care of the children. This results in the condition of the child's attachment style being to his grandmother. Grandmother is a substitute for the mother, so the child's closeness with his mother is replaced. It's different when the child's time with the father dominates. This is due to the exchange of work roles between fathers and mothers, where mothers work outside the home while fathers may work at home or have not even got a job.

If we study further, time together between parents and children is very necessary. This is closely related to improving children's health (both psychologically and physically), building a strong closeness between children and parents, building a child's attachment style to parents, children's emotional temperament, parents' ability to control their children, parents' opportunities to give examples of habits. and life (parents as models), and the way children adjust to their environment (Fitriyah, 2013; Kushlev \& Dunn, 2019; Polatnick, 2002, Ginsburg, 2007; Julal, Carnelley, \& Rowe, 2017; Towler, 2005).

\section{5) Parents of Early Childhood Are Constrained by Knowledge to Stimulate Development}

From the results of interviews, it can be concluded that in general, most parents understand the character of children with good physical, motor, cognitive, language, and socio-emotional development. Physical motor 
development is characterized by agility, courage, and children's health (not easily sick). Cognitive development is characterized by the emergence of curiosity, asking a lot of questions, showing ingenuity, and being able to capture and assemble knowledge. Language development is in line with cognitive development, namely to convey a lot of knowledge in the form of language/speech, can speak fluently and clearly, easily imitate other people's speech, be able to explain and tell stories about something well and fluently, and speak more intensity. Socio-emotional development is characterized by showing sociable behavior, avoiding conflicts/battles with friends, willing to share, understanding other people's conditions, showing intimacy by knowing and greeting other people, not easily afraid of the presence of others, not getting along emotionally and crying easily, and have a lot of friends hanging out with the same age range.

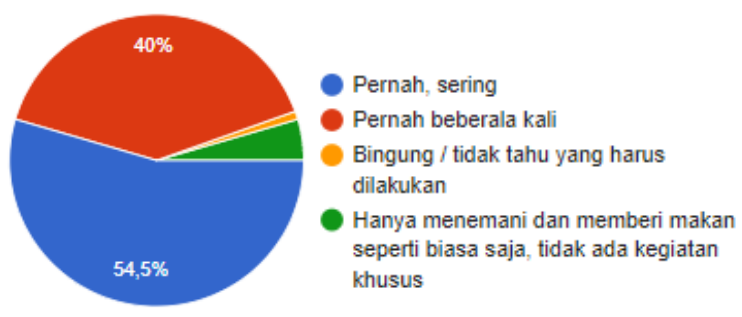

From the results of the interviews, it was also found that more than $90 \%$ of the targets claimed to know how to improve and stimulate the development of their children. Also more than $90 \%$ claimed to be ready / willing to take the time to carry out early childhood development and stimulation activities. More than $90 \%$ of them also have high hopes that their children can have good physical, motor, cognitive, language, and socioemotional development. They also give a lot of statements that it is not difficult to do it. These statements are inversely proportional when the interview is included in the question point "Have you ever consciously / intentionally carried out special activities to improve children's abilities?", $54.5 \%$ answered never, $40 \%$ answered several times, $4.5 \%$ answered only accompanying play and eat everyday, and the rest said they were confused about what to do for the stimulation. $46.4 \%$ of respondents reasoned that working time prevented them from carrying out developmental and stimulating activities in early childhood. $50.9 \%$ reasoned that the density of daily activities hindered them. The rest are for various reasons, such as: children being cared for by parents/ others, busyness and being a mother, and so on.

In several research results, parental knowledge is an important key in controlling the quality of children's growth and development. MarjanovičUmek, L., \& Fekonja-Peklaj, U. (2017) investigated the role of child sex and parental knowledge about child development in parent-child interactive games. In their research, they aimed to analyze the effect of the child's gender on the interactive play behavior of parents and children, as well as to determine the relationship between parents' general knowledge about child development and parental play behavior in two developmental periods, namely toddlerhood and early childhood. The sample included 99 children (50 toddlers 1-3 years; 49 preschoolers aged 3-5 years) and their parents. Parent and child interactive play with a standard set of toys is observed and assessed in the home environment. they found that parental and child play behaviors were closely related in both age groups. In addition, the gender of the child influences the child's play behavior, but not the parent's, so that girls more often define game content, maintain a play frame, and use more symbolic transformations during play than boys. General knowledge of parents about child development is associated with parental education and parental play behavior. These findings apply to a wide range of professionals working with children and their parents in the preschool period.

Parental knowledge related to growth and development will have a lot of impact on the quality of children's growth. Good parental knowledge of the child's growth and development process will be able to prevent children from developing risky behavior, prioritizing the role of kinship in every aspect of a child's life, determining a good child's position in the family organizational structure, and even in cognitive development, which is usually characterized by the development of abilities. language, will affect the speed at which children acquire language. Parents with a good understanding of language teaching will be able to support the development of their children's language skills; it is also very good for sharpening children's cognitive (Padilla-Walker, et al, 2008; Padilla-Walker, et al, 2011; Rowe, 2008)

Parents' knowledge about their child's growth and development is also important, especially if their child has certain diseases, health problems, or developmental disorders. Say for example when a child is born with a low birth weight, malnourished, or premature. Times like this require more attention and knowledge. Parents 
should find someone who is knowledgeable about their child's condition, ask questions, and learn how to treat their child well. Dichtelmiller, et al (1992) in their research found that in fact parents of children who have problems due to underweight need to get sufficient exposure to knowledge, especially regarding how to know and foster mental and psychomotor development in their children.

\section{Conclusion}

The phenomenon of new households who then decide to live with their parents or in-laws after marriage or in the early stages of marriage does not only occur in Indonesia. This has become the culture of society in Asia. Psychologically, they are pressured to have to adjust their daily living habits with the new rules of life, which are applied at the in-laws' house. The goal of supporting financially by covering basic needs (eating, drinking, and buying household items) doesn't always end well. Dependence on parents makes married couples never get independence both economically and in managing their household life. It does not stop there, when children are born and develop, parents-in-law who are too involved or interfere in the development of children result in these young parents not having full policy authority over the development of their children.

Regarding time with children, the facts we found are not as beautiful as people talk about "the importance of the role of a mother who always takes care of her child all the time". Housewives / "stay at home mother" / "full-time mother" cannot always devote time to children. Their homework is not as simple as it seems to the people behind the walls of the house. At home, a housewife spends her time cleaning the house, washing, ironing, cooking, and various other jobs that are not easy or quick to complete. In the end, it is not much different from being reluctant to work in the office, they can rest during the day and will even continue their work in the afternoon. When asked about the dominance of time together, most answered that their children were dominant with their mothers. However, this togetherness apparently cannot be equated with the time of attention. This is because mothers only accompany their children, not to pay attention in full focus to then guide the training and stimulation of their child's growth and development.

Most of the early childhood parents we met said they were ready and would try to provide the best education and stimulation for their children's development. However, when faced with problems of difficulty, work, time, and finances, they also look doubtful and think hard. As if it is true that for them, no matter how they try to respond positively, parenting is a difficult and stressful issue. From the results of interviews, it can be concluded that in general, most parents understand the character of children with good physical, motor, cognitive, language, and socioemotional development.

\section{References}

Dichtelmiller, M., Meisels, S. J., Plunkett, J. W., BOZYTNSKI, M. E. A., Claflin, C., \& Mangelsdorf, S. C. (1992). The relationship of parental knowledge to the development of extremely low birth weight infants. Journal of Early Intervention, 16(3), 210220.

Dillaway, H., \& Paré, E. (2008). Locating mothers: How cultural debates about stay-at-home versus working mothers define women and home. Journal of Family Issues, 29(4), 437-464.

Dixit, A., Bhan, N., Benmarhnia, T., Reed, E., Kiene, S. M., Silverman, J., \& Raj, A. (2021). The association between early in marriage fertility pressure from in-laws' and family planning behaviors, among married adolescent girls in Bihar and Uttar Pradesh, India. Reproductive health, 18(1), 1-9.

Efron Pimentel, E., \& Liu, J. (2004). Exploring nonnormative coresidence in urban China: Living with wives' parents. Journal of Marriage and Family, 66(3), 821-836.

Essa, E. (1996). Introduction to Early Childhood Education. Delmar Publishers. https:// books.google.co.id/books/about/ Introduction_to_Early_Childhood_Educatio. html?id=5vIOAAAAYAAJ\&redir_esc $=y$.

Fitriyah, L. (2013). Hubungan antara tendensi gaya kelekatan dengan penyesuaian sosial pada siswa SMP Islam Paiton yang tinggal di Pesantren. Skripsi Jurusan PsikologiFakultas Pendidikan Psikologi UM.

Ginsburg, K. R. (2007). The importance of play in promoting healthy child development and maintaining strong parent-child bonds. Pediatrics, 119(1), 182-191.

Hurlock, E. B. (1990). Perkembangan Anak (M. Tjandrasa, Trans.). Erlangga. 
Julal, F. S., Carnelley, K. B., \& Rowe, A. (2017). The relationship between attachment style and placement of parents in adults' attachment networks over time. Attachment \& human development, 19(4), 382-406.

Kushlev, K., \& Dunn, E. W. (2019). Smartphones distract parents from cultivating feelings of connection when spending time with their children. Journal of Social and Personal Relationships, 36(6), 1619-1639.

Marjanovič-Umek, L., \& Fekonja-Peklaj, U. (2017). The roles of child gender and parental knowledge of child development in parentchild interactive play. Sex Roles, 77(7), 496-509.

Masganti, S. (2015). PSIKOLOGI PERKEMBANGAN ANAK USIA DINI (Vol. 1). Perdana Publishing. http:// repository.uinsu.ac.id /2872/1/ ISI\%2520PSIKOLOGI\%2520 PERKEMBANGAN\%2520ANAK\%2520USIA $\% 2520$ DINI\%2520MASGANTI.pdf

Masitoh, Setiasih, O., \& Djoehaeni, H. (2005). Pendekatan Belajar Aktif Di Taman KanakKanak. Departemen Pendidikan Nasioanl Direktorat Jendral Pendidikan Tinggi Direktorat Pembinaan Pendidikan Tenaga Kependidikan Dan Ketenagaan Perguruan Tinggi.
Padilla-Walker, L. M., Harper, J. M., \& Bean, R. A. (2011). Pathways to parental knowledge: The role of family process and family structure. The Journal of Early Adolescence, 31(4), 604-627.

Padilla-Walker, L. M., Nelson, L. J., Madsen, S. D., \& Barry, C. M. (2008). The role of perceived parental knowledge on emerging adults' risk behaviors. Journal of Youth and Adolescence, 37(7), 847-859.

Polatnick, M. R. (2002). Quantity time: Do children want more time with their full-time employed parents?. Berkeley Collection of Working and Occasional Papers, 46.

Rowe, M. L. (2008). Child-directed speech: Relation to socioeconomic status, knowledge of child development and child vocabulary skill. Journal of child language, 35(1), 185-205.

Santrock, J. W. (2011). Child Development (Perkembangan Anak) Edisi 11 Jilid 2 (B. Widyasinta, Trans.; 11/2 ed.). Erlangga.

Son, S., \& Bauer, J. W. (2010). Employed rural, low-income, single mothers' family and work over time. Journal of Family and Economic Issues, 31(1), 107-120.

Towler, A. (2005). Charismatic leadership development: Role of parental attachment style and parental psychological control. Journal of Leadership \& Organizational Studies, 11(4), 15-25. 